\title{
Re-designing America's suburbs for the age of climate change and pandemics
}

\author{
Thomas L. Daniels ${ }^{1}[0$
}

Received: 14 January 2021 / Accepted: 16 April 2021 / Published online: 12 May 2021

(c) The Author(s), under exclusive licence to Springer Nature Singapore Pte Ltd. 2021

\begin{abstract}
The USA is the leading emitter of greenhouse gases among the developed countries, in part because it is the only developed country with more of its population in suburbs than in cities. Cities produce less greenhouse gas emissions per capita than suburbs. Meanwhile, the US and the world have been wrestling with the public health emergency of the COVID-19 pandemic. But as US cities recover from the pandemic, they are unlikely to add more population than their suburbs because of changes in favor of working from home, online shopping, and the search for more affordable housing and green space, as well as concerns about population density and contagious diseases. So, the challenge is how to design and redevelop suburbs to make them more environmentally, socially, and economically sustainable to address both climate change and the threat of future pandemics. A sustainable suburb scenario offers an alternative to the sprawling development, separation of land uses and income classes, and automobile dependence that characterizes the typical American suburban landscape. This essay reviews the literature on re-designing suburbs and describes and evaluates both a business-as-usual suburb scenario and a sustainable suburb scenario. Though challenges exist, sustainable suburbs will be needed in order to reduce US greenhouse gas emissions, to achieve greater resilience in adapting to the effects of climate change, and to guard against future pandemics while providing economic opportunities and greater equity over the long run.
\end{abstract}

Keywords Business-as-usual $\cdot$ Climate change $\cdot$ COVID-19 $\cdot$ Scenarios $\cdot$ Sustainable suburb

\section{Scenarios for suburbs in the face of COVID recovery and climate change}

The location of future population growth and development will have major implications for a nation's economy, social interaction, and environmental quality (Beske and Dixon 2018; Calthorpe 2010; Leinberger 2009; Rusk 2001; Williamson and Dunham-Jones 2020). At the start of the decade of the 2020s, two major events - the COVID-19 pandemic and climate change- have presented both immediate and long-term challenges for settlement patterns throughout the world (Goodell 2017; Phillips 2021; Wallace-Wells 2019). By the end of February 2021, the COVID-19 pandemic had infected more than 114 million people worldwide and caused over 2.5 million deaths (New York Times 2021a); in the USA, the virus had killed more than 510,000 people and

Thomas L. Daniels

thomasld@design.upenn.edu

1 Department of City and Regional Planning, University of Pennsylvania, Philadelphia, PA, USA sickened more than 28.6 million (New York Times 2021b). Bringing the COVID-19 virus fully under control will take years and maybe longer (Phillips 2021).

A recent trend has seen many urban inhabitants in the USA moving to suburbs to avoid densely settled places that may aid the spread of the virus, to find lower cost housing now that much work is being done remotely, and to have better access to green space (Bortz 2020; Capps et al. 2020; Clark 2020; Lerner 2020; Matsuda 2020; McPherson 2020). Williamson and Dunham-Jones (2020, p. 16) have observed that "the pandemic seems to have revivified the distrust of compact urbanism". If this urban outmigration continues, US cities are unlikely to add more population than suburbs in the decade of the 2020s and perhaps beyond.

Meanwhile, climate change poses an existential threat to the planet. According to the International Panel on Climate Change, "Human activities are estimated to have caused approximately $1.0^{\circ} \mathrm{C}$ of global warming above pre-industrial levels" (IPCC 2018, p. 4) Scientists warn that keeping temperatures below $1.5^{\circ} \mathrm{C}$ will be necessary to avoid catastrophic changes to the global environment (ibid., p. 11). 
Yet, the expectation is that even with the Paris Agreement of 2015, global temperatures are likely to rise by more than $3{ }^{\circ} \mathrm{C}$ (Wallace-Wells 2019, p. 11). In addition, warmer temperatures will accelerate the melting of the polar icecaps and lead to warmer oceans-contributing to sea level rise, more frequent storms, and storm surges that will threaten to flood low-lying islands and coastal areas throughout the world (Goodell 2017).

Settlement patterns have differing levels of greenhouse gas emissions. A sprawling settlement pattern requires reliance on cars and trucks powered by fossil fuels and results in high per capita carbon emissions (Williamson and DunhamJones 2020, p. 79; Owen 2009, p. 5). By contrast, a compact settlement pattern can support multimodal transportation options, including transit systems (bus and rail), cycling, and walking, which involve little to no greenhouse gas emissions (Calthorpe 2010, p. 3-4). The sprawling pattern-known as drivable suburbia-describes many American suburbs, whereas the compact pattern-known as walkable urbanism-is associated with a relatively small number of US cities (Leinberger 2009, p. 4; Leinberger 2018, p. 23).

The dominant theme of the literature on suburbs over the past 20 years has been to make suburbs more urban to counter the sprawling auto-oriented suburbs (Beske and Dixon 2018; Calthorpe 2010; Dunham-Jones and WIlliamson 2009; Leinberger 2018; Williamson and Dunham-Jones 2020). To achieve greater urbanism, the literature emphasizes retrofitting existing development rather than building on greenfield sites (Beske and Dixon 2018; Leinberger 2018; Williamson and Dunham-Jones 2020). Williamson and Dunham-Jones explain that "greater impacts will be achieved by prioritizing policies that mitigate the negative effects of low-density suburban sprawl, an argument for retrofitting these places rather than building new ones" (Williamson and Dunham-Jones 2020, p. 18).

Prior to the Great Recession of 2008-2010, much attention was paid to creating ecologically sound suburbs on greenfield sites (Steiner et al. 1999; Steinitz et al. 1996; Weller 2008). For example, Steiner et al. evaluated a greenfield suburban area north of Phoenix and called for starting with an ecological inventory and analysis of land forms, climate, rainfall and water sources, wildlife, and vegetation. This approach built on earlier work by Ian McHarg in designing The Woodlands outside of Houston (Daniels 2019). The attempt by Steiner et al. to create an ecologically sustainable suburb resulted in three guiding development principles: a) a continuity of ecosystems; b) a diversity of development densities; and c) the creation of community ( $\mathrm{p}$. 210). A fundamental question asked was whether development could fit into the local ecosystem without destroying it (ibid.). Improved drainage to minimize runoff, soil erosion, and flooding was an important recommendation along with xeriscaping and land preservation to maintain desert open space. Buildings should be compatible with the landscape and climate and open space and viewsheds should be retained, but a sense of community, while important, would also prove elusive (p. 214).

Steinitz et al. studied how urban growth and change in the rapidly developing region between San Diego and Los Angeles might affect one of the most biodiverse areas of the US. In particular, the changes to land use and hydrology from suburban development cause stress on wildlife and biodiversity. "As [human] population increases and development spreads, habitat is lost due to grading, paving, ornamental landscaping, and...There are also indirect effects on vegetation by development through hydrologic and fire influences" (Steinitz et al. 1996, p. 1). Important questions were: How does the landscape operate and is it working well? And, how might the landscape be altered and what predictable differences exist among different development scenarios? (ibid., pp. 6-7).

Weller, while involved in designing a large greenfield suburb outside of Perth, Australia, advocated that landscape designers "[p]rotect, interlink, and enhance existing vegetation deemed of cultural and ecological value" (Weller 2008, p. 258). This would include a "holistic matrix of public open space [integrated with] a comprehensive stormwater management system (ibid.). But the risk is that suburban open spaces "are hard to maintain, fragment clear urban form, dissipate density, and ultimately lack genuine ecological functionality" (ibid. p. 263). Weller concludes with guarded hope, "Whether the spaces we have set aside for environmental protection and habitat linkages do achieve viable ecological corridors in the midst of suburbia remains to be seen" (ibid.).

In sum, while ecological principles remain valid, they are more difficult to implement in a suburban environment that is largely developed. This is important to keep in mind when attempting to retrofit existing suburbs.

Promoting cities to accommodate the majority of America's population growth is a good environmental policy, primarily because cities use less energy and less space per person (Calthorpe 2010, p. 4; Owen 2009, p. 9-10). But except for a brief period after the Great Recession, America's suburbs have grown faster than its core cities since World War II. The 1980 census showed that America had become a suburban nation with more of its population living in suburbs than in central cities or rural areas (Jackson 1985, p. 4). Urban planners have long denigrated suburbs as inferior to cities in terms of culture, population, and size of the economy (ibid. p. 19). However, most Americans now live in suburbs (Dunham-Jones and Williamson 2009, p. 16). Suburbs contain about two-thirds of the nation's jobs, and more than 40 percent of the office space (Calthorpe 2010, pp. 27-28; Dunham-Jones and Williamson 2009, p. 13). And even before the COVID crisis, US suburbs had once 
again been growing faster than cities in the recovery from the Great Recession of 2008-2010 (Cortright 2018, p. 2). It is unlikely that cities will grow faster than suburbs in the decade of the 2020s and perhaps beyond.

Planners, developers, architects, landscape architects, elected officials, businesspeople, environmentalists, and concerned citizens have a unique opportunity to make the suburbs more environmentally, socially, and economically sustainable, while accommodating an influx of new settlers. To facilitate their strategic thinking for implementing greater sustainability, I envision two alternative suburban futures: a Business-as-Usual suburb that is heavily dependent on automobiles and a suburb that seeks to enhance its ecological, social, and economic sustainability.

Socio-ecological practice seeks to produce secure, harmonious, and sustainable outcomes through planning, design, construction, restoration, conservation, and management (Xiang 2019, p. 7). These elements will be used in comparing two future scenarios: a sprawling business-asusual US suburb and an alternative suburb designed for the triple bottom line of economic, environmental, and social sustainability in the age of climate change and pandemics (Daniels et al. 2021).

\section{Scenario planning for visualizing future outcomes}

Scenario planning provides a way to engage a community about its future and a way to analyze uncertainty within a planning process (Avin and Goodspeed 2020, p. 403). Scenarios also enable researchers and practitioners "to identify new concepts of mission and context... with a desired future outcome in mind" (Hirschhorn 1980, p. 172). This paper develops two types of scenarios described by Hirschhorn. First, is a predictive scenario, also known as a business-asusual scenario: what can a suburban community or metro region expect if recent trends in population growth, economic activity, social relations and public health, and environmental conditions continue? More specifically, what will happen to important measures of sustainability, such as greenhouse gas emissions, vehicle miles traveled, public space, public health, ecological systems, median household incomes, and the types and location of new development?

The second type of scenario is an end state scenario, which presents a desired outcome, in this case a suburb that is economically, socially, and environmentally sustainable in the age of climate change and pandemics. The challenge with the end state scenario is to figure out how to get from the current state to the desired end state. The principles underlying the desired end state (the sustainable suburb) should drive the process (Hirschhorn 1980, p. 174). Principles, in this case, are the set of reasons and concepts that will produce the desired sustainable suburb. The ecological principles described by Steiner et al., Steinitz et al., and Weller, if applied in practice, can lead to environmental sustainability. But principles of social equity and economic resilience and opportunity are also important guides for action. How well the principles are applied or can be applied shows up in measurable indicators of sustainability. In short, some suburbs will be more sustainable than others, and the indicators reflect the successes or shortcomings of the efforts to move toward designing a suburb with greater sustainability.

Planners, designers, developers, and elected officials can present the predictive business-as-usual scenario along with one or more alternative end state scenarios at a public meeting, often referred to as a charette. After public comment and adjustment to the scenarios, the public is asked to choose their preferred scenario. Hirschhorn (1980, p. 180) warns that the preferred scenario must be plausible and even surprising to compel a shift in thinking and behavior.

The goal of the charrette is to reach a consensus scenario that the community can work toward through their comprehensive plan, zoning ordinance, subdivision and land development regulations, design guidelines, and infrastructure investments. In addition, households, businesses, developers, designers, and other interested parties can understand how the scenario affects their actions and how their actions can further the achievement of the desired scenario.

\subsection{Defining the business-as-usual scenario for American suburbs}

Much has been written about American suburbs (Daniels 1999; Duany et al. 2000; Dunham-Jones and Williamson 2009; Fishman 1987; Jackson 1985: Orfield 1997; Rome 2001; Steiner et al 1999; Weller 2008; Williamson and Dunham-Jones 2020). Suburbs vary in size, location, population, and development patterns. It is useful to identify three main types of suburbs: (1) Fairly dense inner suburbs, built mainly before 1945 (Jackson 1985, pp. 20-218; Leinberger 2009, p. 6); (2) Low-density auto-dependent suburbs, developed between 1945 and 2020 (Duany et al. 2000, pp. 8-9; Jackson 1985, p. 238; Leinberger 2009, p. xii); and (3) the rural-urban fringe of exurbia between suburbs and the countryside where rural areas are gradually turning into auto-dependent suburbs between 1970 and 2020 (Daniels 1999; Leinberger 2009, p. 7).

The focus of the business-as-usual scenario is on the auto-dependent suburbs because these suburbs contain more people than the other two types of suburbs. The scenario describes the environmental, social, and economic conditions which relate to the triple bottom line of sustainability and five indicators for each condition (see Table 1). The business-as-usual scenario is plausible because it is a continuation of previous practices; it is surprising in the magnitude 


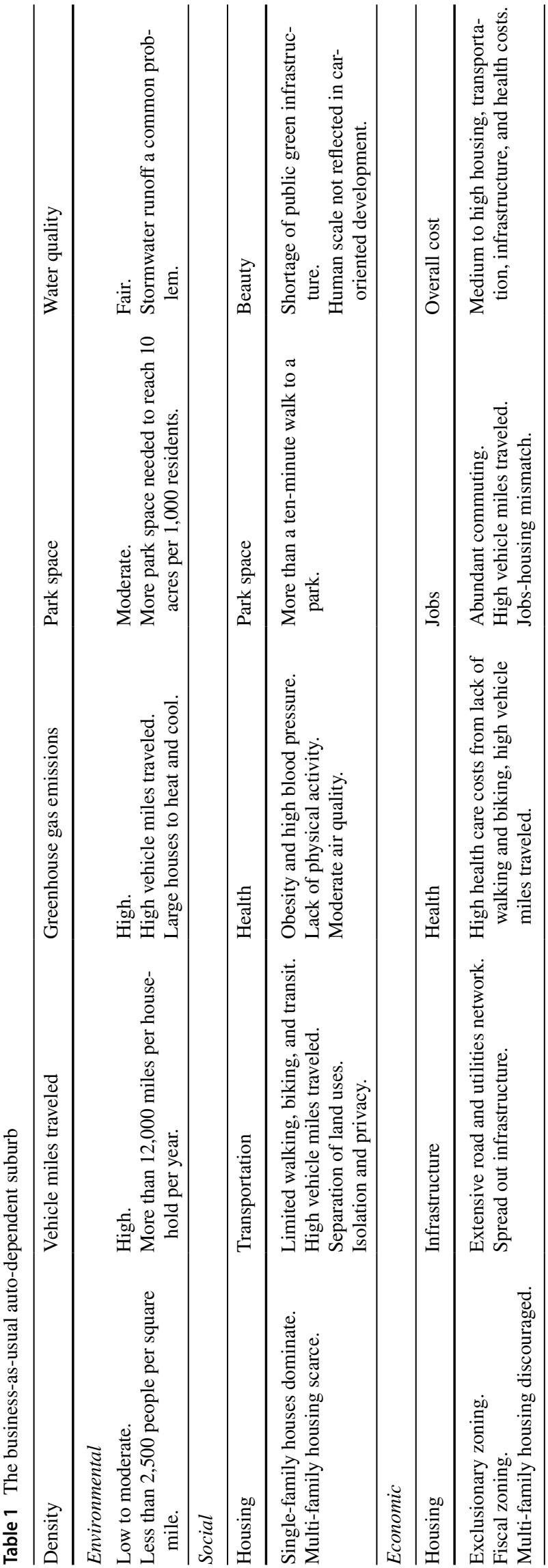

of the expected damage to public health and the environment in its inability to mitigate or adapt to climate change or address the threat of continued pandemics. In short, "[s] uburbia was not designed with climate change, sustainability, or resilience in mind" (Williamson and Dunham-Jones 2020, p. 70).

Duany et al. identify five features of sprawling autodependent suburbs: (1) housing subdivisions which are exclusively residential, so that residents have to drive to access school, jobs, and shopping (see Fig. 1); (2) shopping areas, including commercial strips, malls, and shopping centers with plenty of parking space; (3) office parks with abundant parking space; (4) schools and other public buildings not located in walkable neighborhoods; and (5) roads to connect the separated land uses, which typically suffer from traffic congestion (Duany et al. 2000, pp. 5-7). The public realm is an afterthought (Calthorpe 2010, p. 15). One example is many suburban subdivisions have been built without sidewalks, reducing social interaction and safe walking and biking (Beske 2018, p. 270) (see Fig. 1).

Residential segregation by income exists both within and between suburbs (Kazis 2020, pp. 5-6; Leinberger 2018, p. 28). This adds to the jobs-housing mismatch and results in extensive commuting to and from work (Dowell 2020). Suburban residents have experienced a decline in civic life in part because of time spent in cars (Williamson and DunhamJones 2020, p. 3). Transportation costs are high (Calthorpe 2010, pp. 32, 42; Williamson and Dunham-Jones 2020, p. 3). Calthorpe estimated that an energy-efficient suburban singlefamily home requires almost twice as much energy as an urban condominium and the suburban home uses more than twice as much energy for transportation (Calthorpe 2010, plate 3, See Fig. 1).

Indicators of sustainability encompass environmental, social, and economic categories. Some indicators overlap two or more of the categories. Environmental indicators feature population density, vehicle miles traveled, greenhouse gas emissions and air quality, civic space in the form of park space per 1,000 residents, and water quality (Calthorpe 2010, p. 22; Williamson and Dunham-Jones 2020, p. 16). A city is an incorporated place with a typical density of at least 2,500 people per square mile (US Bureau of the Census 2019); an auto-dependent suburb usually has between 500 and 2,500 people per square mile, and a rural area has fewer than 500 people per square mile. Vehicle miles traveled are directly related to greenhouse gas emissions and inversely related to air quality. Suburban streets feature wide arterials, a few collector streets, and the common use of curving local streets and cul-de-sacs that make driving awkward (Tachieva 2010, p. 1) (See Fig. 1). Auto-dependent suburbs struggle to meet air quality standards, and suburbanites have a much higher carbon footprint than urban dwellers (Leinberger 2009, p. 74: Williamson and Dunham-Jones 2020, p. 


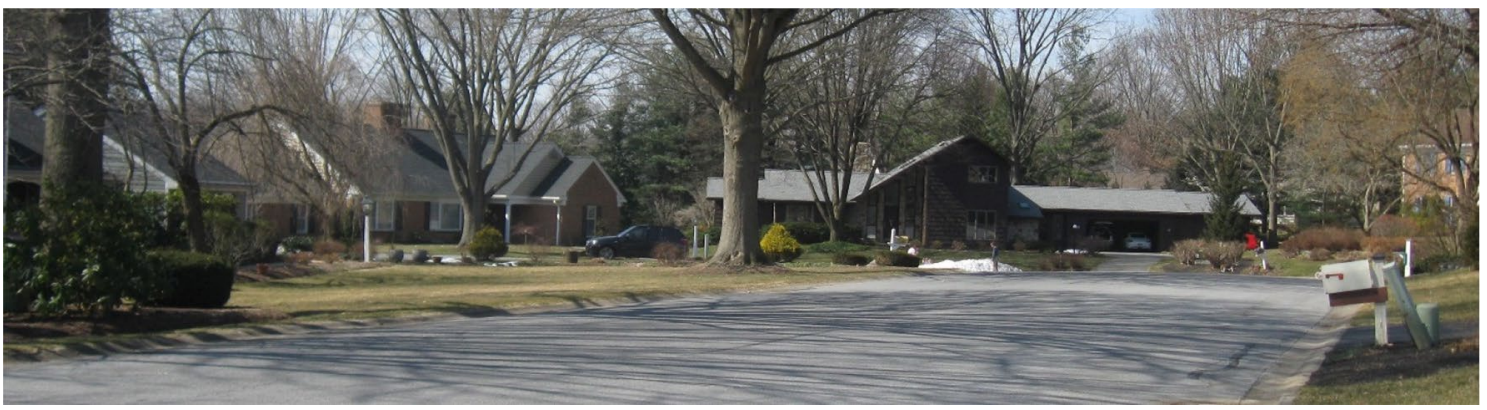

Fig. 1 The cul-de-sac with large single-family homes is a hallmark of the auto-oriented suburb. Note the absence of sidewalks. Cul-de-sacs separate rather than connect neighborhoods and result in awkward street patterns and travel routes

79). A recommended standard for park space is 10 acres for every 1,000 residents, and accessible within a 10-min walk (Trust for Public Land 2019). Water quality should meet the swimmable/fishable standards of the Clean Water Act (Daniels 2014). Stormwater runoff that impairs waterways is a common problem in the suburbs (Leinberger 2009, p. 73; Williamson and Dunham-Jones 2020, p. 72).

Social indicators include housing affordability, the mix of multi-family dwellings and single-family houses, income distribution, and the racial diversity of the population (Calthorpe 2010, p. 15; Williamson and Dunham-Jones 2020, pp. 50-53). Aesthetics also affect social interaction. In many auto-dependent suburbs, there is a lack of beauty because of the shortage of public green infrastructure amid the major highways, big box stores, and acres of parking lots that overwhelm the human scale (Leinberger 2018, p. 15). Human scale means walkable places and chances for social interaction as well as buildings that do not dwarf people (Beske 2018, p. 270).

Economic indicators measure housing affordability, infrastructure costs, health costs, jobs, and the overall cost of living. Housing affordability is an important indicator as it relates to future population growth in the suburbs. Autodependent suburbs are often exclusionary with little space zoned for multi-family housing and requirements of a large lot to build a single-family home; this is closely related to the common suburban practice of fiscal zoning for ample commercial space and high-end residential developments that will generate substantial property tax revenues (Kazis 2020, pp. 5-8; Leinberger 2009, p. 65; Orfield 1997, p. 5). Infrastructure costs rise as settlements are more spread out (Leinberger 2009, pp. 78-79). Health care costs increase with the lack of walking and biking opportunities and autodependence (Ewing et al. 2003, p. 54; Leinberger 2009, pp. 75-76). The number of jobs in a suburb reflects both local economic activity and the jobs-housing imbalance that compels many people to live at a distance from where they work and results in heavy commuting to and from work (Suzuki and Lee 2012, p. 322). Finally, the overall cost of living in an auto-dependent suburb tends to be high because of high housing, infrastructure, transportation, and health costs (Calthorpe 2010, plates 20, 22; Ewing and Hamidi 2015 pp. 417-422; Leinberger 2009, pp. 83-84).

On the positive side, American suburbs have provided single-family housing, known as The American Dream, for millions of households (Jackson 1985). The post-World War II auto-dependent suburbs offered privacy, a yard, and an affordable house (especially in the 1950s and 1960s), better schools, and safety (Calthorpe 2010, p. 47). Some suburbs burgeoned into Edge Cities, economic powerhouses with more jobs than bedrooms (Garreau 1992, p. 7). But overall, suburbs built since 1945 have created patterns of growth with negative impacts on the environment and health care costs. American suburbs have been perceived as healthier places to live than cities, though Ewing et al. reported that adults living in sprawling outer metropolitan counties had higher body mass indices (BMIs) and were more likely to be obese (BMI $\geq 30)$ and had more hypertension than people living in compact metro counties (Ewing et al. 2003, p. 54).

In sum, American auto-dependent suburbs are not sustainable in terms of transportation options, greenhouse gas emissions, infrastructure costs, health care costs, housing affordability, overall cost of living, aesthetics, recreational opportunities, and social equity (Calthorpe 2010, p. 48; Ewing and Hamidi 2015, pp. 417-422). So, how do we make suburbs more sustainable in the era of climate change and pandemics?

\subsection{Defining the sustainable American suburb}

Architects, landscape architects, planners, developers, and academics have offered advice on how to create suburbs that are more sustainable. But much of this advice preceded the recognition of climate change as an existential threat beginning in the early 2000s, and the primary aim was to make suburbs more urban (Beske and Dixon 2018; Duany et al. 2000). Lately, the COVID-19 crisis has not only called into question the wisdom of promoting cities as environmentally 
healthier places but has also demonstrated a high demand for green space (McCormick 2020). The response to the pandemic has yet to be implemented in suburbs. Yet, it is

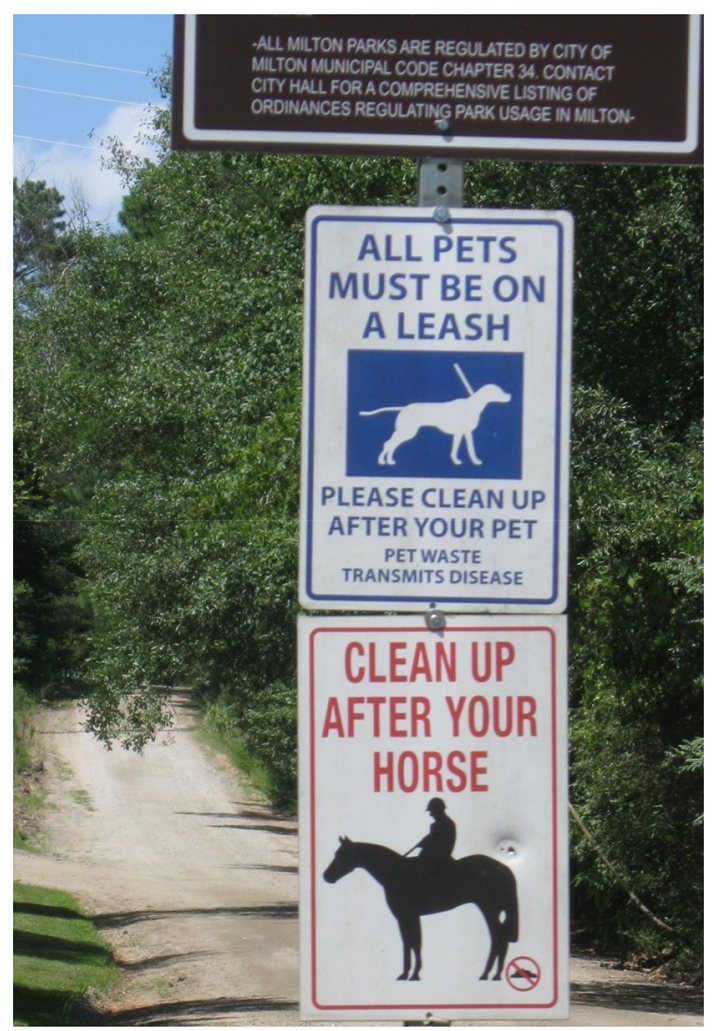

Fig. 2 Multi-Use Trail in the City of Milton Georgia, an outer suburb of Atlanta. The signs ask trail users to respect other people and to be environmentally responsible by putting all pets on a leash and cleaning up after the pets, especially horses clear that New Urbanism which emphasizes building form and relation to the public realm is not sufficient, and both cities and suburbs must emphasize public health, resilient spaces and buildings in mixed-use developments, along with ample green space and trails for recreation, social distancing, absorbing stormwater, and reducing the heat island effect (see Fig. 2). This push for more green space may also help to restore and repair ecological systems of hydrology, vegetation, wildlife habitat, and biodiversity. So far, the most common response to climate change in suburbs has been green infrastructure to manage stormwater runoff brought on by more frequent and intense storms associated with climate change (see Promenade of Wayzata, MN, Williamson and Dunham-Jones 2020, pp. 152-156). Nonetheless, greater density is needed to accommodate increasing numbers of suburban dwellers and reduce inequity by providing affordable housing (Galante 2020) (see Fig. 3).

The three interrelated areas of sustainability: economy, society, environment provide a useful framework for developing a sustainable suburb scenario in the age of climate change and pandemics. Unlike the business-as-usual scenario, American suburbs could become more ecologically resilient, economically more vibrant, and socially more equitable through creative planning, design, and redevelopment while embracing new inhabitants.

The environment of the sustainable suburb scenario has a higher density of population and development than the automobile-oriented suburb (Dunham-Jones and Williamson 2009, p. vi; Leinberger 2018, p. 16; Tachieva 2010, p. 8). Although at first this greater density sounds like social engineering, the demand for denser, more walkable places has been growing (Ewing and Hamidi 2015, p. 413; Leinberger 2018, pp. 25-26). Greater suburban density is necessary in

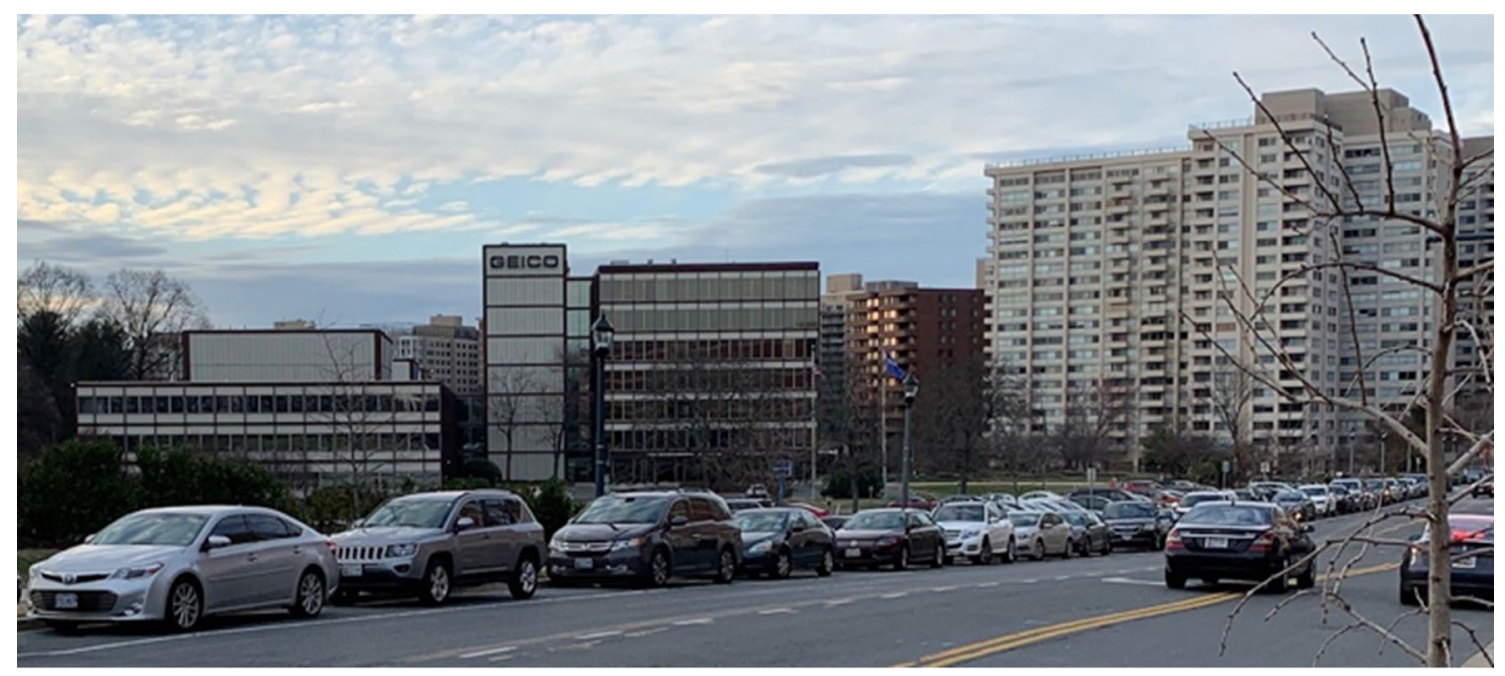

Fig. 3 Dense, mixed-use development within walking distance of the DC Metro, Bethesda, MD. Making suburbs look and feel more urban while retaining a human scale and allowing for transportation choices also increases their sustainability 
order to reduce vehicle miles traveled, cut greenhouse gas emissions, enable feasible transit, promote walking and biking, and reduce impervious surfaces and stormwater runoff (Dunham-Jones and Williamson 2009, p. viii; McCormick 2017). But how dense should suburbs be, especially in the post-COIVD era? At least 7.5 dwelling units per acre are needed to support transit (see Fig. 3). Yet, some parts of a suburb will be more densely settled than others. Still, required minimum lot sizes for single-family homes should shrink to as low as 3,000 square feet and allowing accessory dwelling units and duplexes and triplexes in traditionally single-family zoning districts would help to add density. More multi-family housing is a must both to support transit, greater equity, affordable housing options, and to reduce the jobs-housing imbalance and decrease commuting traffic (Leinberger 2018, p. 26; see Assembly Square, Somerville, MA, Williamson and Dunham-Jones 2020, pp. 236-241). Mixed-use town centers can add to density, walkability, green space and economic activity (see South Lake, Texas, Steuteville 2019).

Cars will still be a major mode of transportation in a sustainable suburb. The growing popularity of electric vehicles will be important to reduce greenhouse gases and move toward net zero emissions. Complete streets can combine green space for shade and absorbing stormwater along with accommodating cars, transit, cyclists, and pedestrians; and narrow streets and on-street parking can slow traffic on local streets (Beske 2018, p. 269; see Wauwatosa, WI Schmitt 2014). The key idea is transportation choice. For example, a transit system option is needed for climate change mitigation, even though it is not an attractive option during a time of pandemic as we have seen. During the pandemic, driving has been much reduced as well because of working at home and increased food and online shopping deliveries. If suburban transit is cheaper and more convenient than driving, it will win out, except in times of pandemic.

Public green space is important for recreation and mental health. Providing at least 10 acres of public parkland for every 1,000 residents is already a recommended standard along with having parkland within a ten-minute walk (Trust for Public Land 2019). More walking and biking opportunities will enable more social interaction, better health outcomes, improved air quality, and lower greenhouse gas emissions to mitigate climate change. In the age of COVID19 , the demand for outdoor recreation in public green spaces has been strong (McCormick 2020). Additional park space is needed in many suburbs. New park space should feature greater convenience and more walking and biking opportunities to neighborhood pocket parks with active recreation and within larger parks that have a mix of active and passive space. Park space ideally should be designed to provide for better health outcomes through passive recreation while social distancing or social interaction and sports, depending on the local public health situation. This dual design of parks would reduce the need to close public parks to discourage the spread of a pandemic and help residents maintain physical and mental health.

Finally, if more public green space is provided, less private green space is needed. Lot sizes for single-family homes can be smaller, especially less than the suburban default size of a quarter of an acre, and more multi-family housing allowed. In this way, both park space and residential density increase. Much of the recent literature on suburban redevelopment has emphasized making suburbs more urban (see Fig. 3). However, differences remain in the design of cities and suburbs in space, building scale, and density. For example, trails are more common in suburbs (see Fig. 2). The Le Corbusier towers in the park design, popularized in cities is not a suburban design. The sustainable suburban design is a more human scale of multi-family housing (see Fig. 3) together with, ideally, small residential lots of, say, 5,000 square foot maximum lot size. These suburban residential designs have adequate density to support transit. Auto-dependent suburban density is typically less than 2,500 people per square mile and a sustainable suburban density will need to approach urban-level densities 3,000 to 5,000 people per square mile. The upper end of this density range is comparable to Portland, Oregon, one of our most livable cities (World Population Review 2021).

The potential economic benefits of a sustainable suburb are lower housing, transportation, and infrastructure costs as well as savings from avoided property losses through greater climate resilience. The use of green infrastructure for shade to minimize the heat island effect and to absorb stormwater will result in less energy use for cooling and improved water quality and less flooding during storm events. Lower health care costs are likely as people take advantage of walking, biking, and recreation opportunities (Williamson and Dunham-Jones 2020, p. 18).

Socio-ecological practice seeks to produce secure, harmonious, and sustainable outcomes with six interrelated types of human action and social processes: planning, design, construction, restoration, conservation, and management (Xiang 2019 , p. 7). The sustainable suburb scenario for the era of climate change and pandemics contains these six activities and the actors who carry them out. Planners through land use plans, regulations, and public infrastructure investment influence the pattern of public and private development; zoning must allow adequate densities, especially to support transit, as well as the mixing of residential and commercial land uses to enable walking and biking. In addition, the planning and acquisition of land for public parks and trails are important for recreation opportunities. In short, the planners and elected officials set the ground rules for development that must be attractive to developers and designers but maintain environmental quality and responsible public budgets. 
Architects and landscape architects must use their design skills to produce a human scale of development, a sense of place, a positive interaction between private development projects and the public realm, and open space that supports or rehabilitates ecological systems (Beske 2018, p. 269). Construction should meet LEED-certified standards or those of the International Green Building Code to minimize energy use and produce healthy buildings. The SITES rating and certification system can be used in tandem with LEED to promote development that minimizes water demand, stormwater runoff, and energy use and increases outdoor recreation opportunities and improves air quality and hence mitigates climate change (Green Business Certification, Inc. 2021).

Restoration of buildings, brownfield sites, and waterways is essential for community health. Conservation of wetlands, woodlands, and riparian areas is important for wildlife habitat, biodiversity, and overall community resilience to climate change (Meerow et al. 2016). Management of the sustainable suburb combines private and public responsibilities and opportunities. One of the hallmarks of suburban development between 2010 and 2020 is the greater use of public-private partnerships (Williamson and Dunham-Jones 2020). Community management must emphasize economic diversification and opportunity, workforce development, social diversity, affordable housing, safe and attractive green space, resilient buildings and infrastructure and ecological systems, and the connections of the transportation and environmental systems to the central city and the rest of the metro area.

\subsection{Obstacles and opportunities for the sustainable American suburb}

A scenario must be realistic in order to be considered. How do we get an integrated sustainable suburb through retrofitting? Quite simply, the actors that create and manage suburbs must be able to work together. The obstacles to developing and maintaining sustainable suburbs are many, but so too are the opportunities (see Table 2).

Socio-ecological practice seeks to produce outcomes that overcome obstacles and take advantage of opportunities. This approach can provide planners, elected officials, architects and landscape architects, developers, environmentalists, and concerned citizens with cogent economic, social, and environmental with arguments why sustainable suburbs are both beneficial and urgently needed in the age of climate change and pandemics.

Table 2 The sustainable suburb scenario

\begin{tabular}{|c|c|c|c|c|c|c|}
\hline Population density & Vehicle miles traveled & Greenhouse gas emissions & \multicolumn{2}{|c|}{ Park space } & \multicolumn{2}{|c|}{ Water quality } \\
\hline \multicolumn{7}{|l|}{ Environmental } \\
\hline $\begin{array}{l}\text { A minimum of 2,500 people } \\
\text { per square mile }\end{array}$ & $\begin{array}{l}\text { Low to medium. } \\
\text { Under } 10,000 \text { miles per } \\
\text { year. } \\
\text { Increased use of electric } \\
\text { vehicles. }\end{array}$ & Low & \multicolumn{2}{|c|}{$\begin{array}{l}10 \text { acres or more per } 1,000 \\
\text { residents }\end{array}$} & \multicolumn{2}{|c|}{$\begin{array}{l}\text { Good quality. } \\
\text { Little stormwater runoff } \\
\text { with use of green } \\
\text { infrastructure. }\end{array}$} \\
\hline Housing & Transportation & Health & Park spac & & \multicolumn{2}{|l|}{ Beauty } \\
\hline \multicolumn{7}{|l|}{ Social } \\
\hline More multi-family housing $\mathrm{N}$ & $\begin{array}{l}\text { More walking, biking, and } \\
\text { transit. } \\
\text { Less driving. }\end{array}$ & $\begin{array}{l}\text { Better air quality, } \\
\text { More physical activity in } \\
\text { walking and biking. }\end{array}$ & \multicolumn{2}{|c|}{$\begin{array}{l}\text { Within a ten-minute walk } \\
\text { of a park. }\end{array}$} & \multicolumn{2}{|c|}{$\begin{array}{l}\text { Nature and green infra- } \\
\text { structure. }\end{array}$} \\
\hline Housing & Infrastructure & Health & & Jobs & & Overall cost \\
\hline \multicolumn{7}{|l|}{ Economic } \\
\hline $\begin{array}{l}\text { End exclusionary zoning. } \\
\text { Greater mix of housing types } \\
\text { and affordability of housing. } \\
\text { Energy efficient buildings. }\end{array}$ & $\begin{array}{l}\text { Fewer roads and utilities. } \\
\text { Renewable energy. }\end{array}$ & \multicolumn{2}{|c|}{$\begin{array}{l}\text { Lower health costs with less } \\
\text { commuting and more physi- } \\
\text { cal activity. }\end{array}$} & \multicolumn{2}{|c|}{$\begin{array}{l}\text { More people working from } \\
\text { home. } \\
\text { Lower com-muting costs. }\end{array}$} & $\begin{array}{l}\text { Lower } \\
\text { housing, } \\
\text { transpor- } \\
\text { tation, } \\
\text { infrastruc- } \\
\text { ture, and } \\
\text { health } \\
\text { costs. } \\
\text { Savings } \\
\text { from } \\
\text { greater } \\
\text { climate } \\
\text { resilience. }\end{array}$ \\
\hline
\end{tabular}


One overarching obstacle is the need to be clear about what sustainability principles are, how to apply them in practice, and what indicators to use to measure successes or shortcomings in new and retrofitted developments. The traditional blanket definition of sustainability principles is valid, but broad and difficult to measure: "Sustainable development is development that meets the needs of the present without compromising the ability of future generations to meet their own needs" (World Commission on Environment and Development 1987, p. 41).

Environmental, economic, and social sustainability principles exist for the triple bottom line of sustainability: 1) environmental quality and resilience; 2) economic efficiency, affordability, and job opportunities; and 3) social equity in the distribution of wealth and access to housing and amenities. Indicators include: a) population density; b) vehicle miles traveled; c) greenhouse gas emissions; d) park space; e) water quality; f) housing affordability; g) infrastructure costs; h) jobs; and i) public health (see Tables 1 and 3).

Quite simply, the needs of future generations will be greater than today because there will likely be more people to support. This means changes in planning and development practices along with substantial costs in making progress toward sustainability; for example, mitigating and adapting to climate change will be expensive, requiring trillions of dollars of investments in renewable energy, transportation systems, building retrofits, and new industrial processes (IEA 2020, pp. 167-170). In addition, "Governments will need to develop explicit settlements strategies to guide the process of urbanization, taking the pressure off the largest urban center[s] and building up smaller towns and cities, more closely integrating them with their rural hinterlands" (World Commission on Environment and Development 1987, 22). Calthorpe echoes the need to integrate cities and suburbs in metropolitan regions and emphasizes that "Only a regional plan can create a framework for communities of differing scales and intensities," especially for transportation networks and environmental systems (Calthorpe 2010, p. 4). And the need to anticipate future pandemics to protect public health must now be factored into suburban design (Phillips 2021; Williamson and Dunham-Jones 2020, p. 16).

Perhaps the four greatest obstacles to creating the sustainable suburb are: (1) the existing pattern of development which fragments and degrades the natural environment and resists densification (see Fig. 1); (2) the Not In My Backyard (NIMBY) sentiment against new development and higher density; (3) the cost of providing safe, convenient, and reliable transit; and (4) combining the many necessary elements and designs into an integrated ecologically robust, healthy, and attractive suburb. Many suburbs feature a separation of land uses, no clear center of the community, and relatively low density. Retrofitting properties involves changes in zoning to promote greater density and mixed-uses and then building these projects (Dunham-Jones and Williamson 2008 , p. xii). Changing the zoning from single-family residential to multi-family or mixed use is not easy to do politically; and densifying an already built-up single-family subdivision is physically difficult. The common cul-de-sacs and looping streets, rather than a rectilinear grid with small blocks, add to the redevelopment challenges (Williamson and Dunham-Jones 2020, p. 5) (see Fig. 1).

Many suburban dwellers are concerned about the value of their homes and resist new developments involving higher densities and locally unwanted land uses (LULUs) that they perceive as threatening to reduce their property values (Dear 1992). The NIMBY attitude has translated into political power to work against higher densities and even transit options in the suburbs. The lack of density affects transportation options, making transit infeasible. In short, "the transportation system our society chooses to invest in will dictate the form of the built environment" (Leinberger 2009, p. xv). Suburbanites do not seem enamored of buses. Light rail, commuter rail, bus rapid transit, and even subways are far more expensive to install and operate. So, widespread densifying of single-family districts does not seem possible. But new construction, in a mixed-use and compact form, can be located near transit stations and promote walking and biking. Similarly, redeveloping underperforming shopping centers into mixed-use projects on transit routes holds

Table 3 Obstacles and opportunities in moving toward the sustainable suburb

\begin{tabular}{|c|c|c|}
\hline Economic & Social & Environmental \\
\hline \multicolumn{3}{|l|}{ Obstacles } \\
\hline $\begin{array}{l}\text { The cost of new infrastructure, } \\
\text { especially transit. } \\
\text { The cost of retrofitting vs new } \\
\text { construction on greenfield } \\
\text { sites. }\end{array}$ & $\begin{array}{l}\text { Not in My Backyard (NIMBY) sentiment. } \\
\text { Political opposition to changing zoning } \\
\text { for multi-family and mixed-use develop- } \\
\text { ments. }\end{array}$ & $\begin{array}{l}\text { Existing development patterns. } \\
\text { Increasing density while maintaining air and water quality, } \\
\text { avoiding traffic congestion, and providing more public green } \\
\text { space. }\end{array}$ \\
\hline \multicolumn{3}{|l|}{ Opportunities } \\
\hline $\begin{array}{l}\text { More people working remotely. } \\
\text { More online shopping. }\end{array}$ & $\begin{array}{l}\text { Greater diversity. } \\
\text { Yes in My Backyard (YIMBY) sentiment. }\end{array}$ & $\begin{array}{l}\text { Connecting with neighboring suburbs and the region for transit, } \\
\text { trails, and parks. }\end{array}$ \\
\hline
\end{tabular}


considerable promise (see Belmar, Lakewood, CO DunhamJones and Williamson 2009, pp. 159-171). Re-zoning land from commercial to mixed use along transportation corridors together with investments in green infrastructure also has considerable potential. Form-based codes can encourage development by placing few limits on land uses, but also require well-designed buildings and sidewalks to promote walkability and enhance the public realm (ibid., p. 12).

Many suburbs have features of sustainability (Beske and Dixon 2018; Williamson and Dunham-Jones 2020). These range from the large-scale re-development of dead malls into mixed-use town centers to creating trail networks to re-purposing small properties in what I characterize as tactical suburbanism (see Lydon and Garcia 2015). But an entire overhaul of an existing suburb does not appear in the literature.

The recent trend of more people working remotely from home at least part of the time is likely to continue after the COVID pandemic has abated. This trend along with the growth of online shopping means less dependence on a car. A safe, high-quality living environment is therefore more important than ever. Socially, opportunities exist for a greater diversity of residents by race and income, as well as more openness to increasing density in the form of multifamily housing and mixed-use developments; but the more buildings, the more green space is needed for safe gathering, recreation opportunities, and the maintain ecological systems. No growth is not an option for a sustainable suburb. Although the Yes in my backyard (YIMBY) movement has focused mainly on cities, a sustainable suburb must be open to newcomers as well as a variety of affordable housing options.

Finally, a sustainable suburb cannot exist as an island of sustainability. It must be connected to other sustainable suburbs and a sustainable metro region in order to have successful transportation and environmental systems and accommodate a regional fair share of affordable housing to minimize the jobs-housing mismatch that results in traffic congestion (Orfield 1997, p. 7). A major problem in metro areas is the large number of suburban governments and the competition for property tax and sales tax base (Daniels 1999; Rusk 2001 , p. 6). One solution would be a regionally elected government that would create a "regional city" (Calthorpe 2010, pp. 16-17; Calthorpe and Fulton 2001; Duany et al. 2000, p. 227; Orfield 1997, p. 6).

\section{Scenario planning, socio-ecological practice, and the sustainable suburb}

Scenario planning offers a detailed way to anticipate the variety of outcomes from different land use planning, design and regulatory regimes, and infrastructure investment. The sprawling, automobile-oriented businessas-usual suburb in the US is not sustainable in the era of climate change and pandemics. If the business-as-usual scenario of sprawling suburban development continues, the US will likely see upward pressure on greenhouse gas emissions, traffic congestion, loss of open space, and general environmental degradation along with more social separation and isolation. An alternative scenario, and hopefully the preferred scenario, is a suburb that seeks greater economic opportunity, social equity and safety, ecological health, and environmental resilience. However, this alternative suburb is not a panacea for solving the twin challenges of mitigating and adapting to climate change. Cities offer the best alternative for settlement patterns that minimize greenhouse gas emissions. But the expectation that large numbers of suburbanites will move to cities over the next few decades is likely to be wishful thinking. The aftermath of the COVID pandemic is likely to linger, along with a fear of similar pandemics erupting, especially in densely settled cities. Therefore, designing and retrofitting suburbs for greater sustainability will be imperative.

The sustainable suburb scenario will require a change in lifestyles: a greater use of transit, more walking, and more people living in mixed use, multi-family developments. Stakeholders, including planners, designers, developers, elected officials, businesspeople, environmentalists, and concerned citizens, can use the sustainable suburb scenario to determine whether a proposed commercial or residential development, or infrastructure project adds to or detracts from sustainability.

Socio-ecological practice can help identify actions and processes that will produce greater sustainability through planning, design, construction, restoration, conservation, and management. In turn, this information can help planners, designers, elected officials, developers, and residents to weigh their decisions about suburban development. Although this paper focused on suburbs in the US, planning and development practices that make progress toward greater economic, social, and environmental sustainability apply across the globe. Suburbs everywhere in the era of pandemic threats and climate change must take action to mitigate greenhouse gas emissions, become more resilient to climate-related shocks, improve social relations, public health, and affordable housing options, support a variety of jobs and businesses, and maintain ecological systems. 


\section{Declarations}

\section{Conflict of interest}

The author states that there is no conflict of interest.

\section{References}

Avin U, Goodspeed R (2020) Using exploratory scenarios in planning practice. Jour Am Plan Assoc 86(4):403-416. https://doi. org/10.1080/01944363.2020.1746688

Beske J (2018) In Beske and Dixon, eds. Suburban re-mix: creating the next generation of urban places. Island Press, Washington, pp 267-289.

Beske J, Dixon D (2018) Suburban re-mix: creating the next generation of urban places. Island Press, Washington

Bortz D (2020) How the pandemic is persuading millennials to leave the city and make living in the suburbs ... cool? Money, August 18, 2020. https://money.com/coronavirus-milliennials-homeb uying-suburbs/. Accessed 30 Oct 2020.

Calthorpe P (2010) Urbanism in the age of climate change. Washington, DC: Island Press. Calthorpe, P, Fulton, W (2001) The regional city: Planning for the end of sprawl. Island Press, Washington

Capps K, Patino M, Merrill, D. (2020) In the U.S., city rents are falling, and suburban rents are climbing. Bloomberg CityLab 30 Oct 2020. https://www.bloomberg.com/news/articles/2020-1030/where-rents-are-falling-and-where-they-are-rising? $\mathrm{cmpid}=$ BBD103020_CITYLAB\&utm_medium $=$ email\&utm_source $=$ newsletter\&utm_term $=201030 \& u t m \_$campaign $=$citylabdaily. Accessed 30 Oct 2020.

Clark P (2020) Race to the suburbs sparks boom in rental-house construction. Bloomberg News, November 18, 2020. https:// www.bloomberg.com/news/articles/2020-11-18/race-to-thesuburbs-sparks-boom-in-rental-house-construction. Accessed 29 Dec 2020.

Cortright J (2018) Are Americans fleeing cities for suburbs? Not so fast." CityLab. June 11, 2018. https://www.citylab.com/life/ 2018/06/are-americans-fleeingcities-for-suburbs-not-so-fast/ 562580/. Accessed 5 Oct 2020.

Daniels T (1999) When city and country collide. Island Press, Washington, DC

Daniels T (2014) The environmental planning handbook. American Planning Association, Chicago

Daniels T (2019) McHarg's theory and practice of regional ecological planning: retrospect and prospect. Socio Ecol Pract Res 1(34):197-208. https://doi.org/10.1007/s42532-019-00024-4

Daniels T, Chan J, Kankam S, Murphy M, Day D, Inkoom J, Koo H (2021) Four shareworthy SEPR scenario ideas. Socio Ecol Pract Res 3(1):9-15. https://doi.org/10.1007/s42532-020-00072-1

Dear M (1992) Understanding and overcoming the NIMBY syndrome. J Am Plan Assoc 58(3):288-300. https://doi.org/10. 1080/01944369208975808

Dowell E (2020) Job sprawl results in unemployment for lowincome urban residents. Washington, DC: US Bureau of the Census. https://www.census.gov/library/stories/2020/03/spati al-mismatch-when-workers-can-not-get-to-jobs-in-suburbs. html. Accessed 6 Mar 2021.
Duany A, Plater-Zyberk E, Speck J (2000) Suburban nation: the rise of sprawl and the decline of the American dream. North Point Press, New York

Dunham-Jones E, Williamson J (2008) Retrofitting suburbia: urban design solutions for redesigning suburbs. John Wiley \& Sons Inc, New York

Ewing R, Hamidi S (2015) Compactness versus sprawl: a review of recent evidence from the United States. J Plan Lit 30(4):413432. https://doi.org/10.1177/0885412215595439

Ewing R, Schmid T, Killingsworth R, Zlot A, Raudenbush S (2003) Relationship between urban sprawl and physical activity, obesity, and morbidity. Am J Health Prom 18(1):47-57

Fishman R (1987) Bourgeois utopias: the rise and fall of suburbia. Basic Books, New York

Galante C (2020) Now is the time to embrace density. New York Times, May 12, 2020, www.nytimes.com/2020/05/12/opinion/ sunday/urban-density-inequality-coronavirus.html. Accessed 29 Dec 2020.

Garreau J (1992) Edge city: life on the new frontier. Anchor Books, New York

Goodell J (2017) The water will come: rising seas, sinking cities, and the remaking of the civilized world. Little, Brown and Company, New York

Green Business Certification, Inc. (2021). The sustainable SITES initiative. https://www.sustainablesites.org/certification-guide. Accessed 5 March 2021.

Hamidi S, Sabouri S, Ewing R (2020) Does density aggravate the COVID-19 pandemic? J Am Plan Assoc 86(4):495-509. https:// doi.org/10.1080/01944363.2020.1777891

Hirschhorn L (1980) Scenario writing: a developmental approach. J Am Plan Assoc 46(2):172-183. https://doi.org/10.1080/01944 368008977030

International Energy Agency (2020) Energy technology perspectives 2020. IEA, Paris

International Panel on Climate Change (IPCC) (2018) Global warming of $1.5^{\circ} \mathrm{C}$ : summary for policymakers. World Meteorological Organization, Geneva, Switzerland.

Jackson K (1985) Crabgrass frontier: the suburbanization of the United States. Oxford University Press, New York

Kazis N (2020) Ending exclusionary zoning in New York City's suburbs. New York University Furman Center, New York

Leinberger C (2018) Urbanizing the suburbs: The major development trend of the next generation. In Beske and Dixon, eds., Suburban re-mix: Creating the next generation of urban places. Washington, DC: Island Press, 15-31.

Leinberger C (2009) The option of urbanism: Investing in a new American dream. Island Press, Washington

Lerner M (2020) Choosing the suburbs over city life during the pandemic. Washington Post, October 16, 2020. https://www.washi ngtonpost.com/realestate/choosing-the-suburbs-over-city-lifeduring-the-pandemic/2020/10/15/01c94c5e-e716-11ea-97e094d2e46e759b_story.html. Accessed 30 Oct 2020.

Lydon M, Garcia, (2015) Tactical urbanism: short-term action for long-term change. Island Press, Washington

Matsuda A (2020) Nearly 70\% of CEOs expect to downsize offices: KPMG: Corporate executives see benefit of work-from-home. The Real Deal, September 03, 2020. https://therealdeal.com/ 2020/09/03/nearly-70-of-ceos-expect-to-downsize-offices-survey/ Accessed 08 Nov 2020.

McCormick K (2020) Room to Roam: The Pandemic Has Underscored the Need for More Urban Parks. So What Comes Next? Landlines, October 2020. https://www.lincolninst.edu/publi cations/articles/2020-10-room-roam-pandemic-urban-parkswhat-comes-next. Accessed 12 Mar 2021.

McCormick K (2017) Transforming inner-ring suburbs with walkable mixed-use development. Urban Land, August 21, 2017. 
https://urbanland.uli.org/development-business/inner-ring-revit alization-transforming-aging-suburbs-walkable-mixed-usedevelopment/. Accessed 6 Mar 2021.

McPherson M (2020) Here's where home prices soared the most during the pandemic. Inman, December 15, 2020. https://www. inman.com/2020/12/15/heres-where-home-prices-soared-themost-during-the-pandemic/. Accessed 29 Dec 2020.

Meerow S, Newell JP, Stults M (2016) Defining urban resilience: a review. Landsc Urban Plan 147:38-49

New York Times (2021a) Coronavirus world map: Tracking the global outbreak. March 1, 2021. https://www.nytimes.com/ interactive/2020/world/coronavirus-maps.html?action=click\& module $=$ Spotlight \&pgtype $=$ Homepage. Accessed 1 Mar 2021.

New York Times (2021b) Coronavirus in the U.S.: Latest map and case count. March 1, 2021. https://www.nytimes.com/inter active/2020/us/coronavirus-us-cases.html. Accessed 1 Mar 2021

Orfield M (1997) Metropolitics: a regional agenda for community and stability. The Brookings Institution, Washington

Owen D (2009) Green metropolis: Why living smaller, living closer, and driving less are the keys to sustainability. Riverhead Books, New York

Phillips N (2021) The coronavirus is here to stay-here's what that means. Nature 590:382-384. https://doi.org/10.1038/ d41586-021-00396-2

Rome A (2001) The bulldozer in the countryside: suburban sprawl and the rise of American environmentalism. Cambridge University Press, New York

Rusk D (2001) Inside game/outside game: winning strategies for saving urban America. The Brookings Institution, Washington

Schmitt A (2014) A Milwaukee suburb turns to complete streets to spur business. https://usa.streetsblog.org/2014/09/29/a-milwaukee-suburb-turns-to-complete-streets-to-spur-business/. Accessed 8 Mar 2021.

Steiner F, McSherry L, Brennan D, Soden M, Yarchin J, Green D, McCarthy JM, Spellman C, Jennings J, Barré K (1999) Concepts for alternative suburban planning in the northern phoenix area. J Am Plan Assoc 65(2):207-222. https://doi.org/10.1080/01944 369908976048

Steinitz C, Binford M, Cote P, Edwards T Jr, Forman ES, Johnson R, Kiester C, Mouat R, Olson D, Shearer D, Toth A, Wills R, R, (1996) Biodiversity and landscape planning: alternative futures for the region of camp Pendleton, California. Strategic Environmental Research and Development Program, Arlington

Steuteville, R (2019) Designing and building mixed-use centers in the suburbs. https://www.cnu.org/publicsquare/2019/12/11/designingand-building-mixed-use-centers-suburbs. Accessed 7 Mar 2021.

Suzuki T, Lee S (2012) Jobs-housing imbalance, spatial correlation, and excess commuting. Transportation Research Part A: Policy and Practice 46(2):322-336. https://doi.org/10.1016/j.tra.2011. 10.004

Tachieva G (2010) Sprawl repair manual. Island Press, Washington

Trust for Public Land (2019) The trust for public land and partners launch 10-minute walk campaign partnership fund and announce first year grantee recipients. New York: Trust for Public Land, May 1, 2019. https://www.tpl.org/media-room/trust-public-landand-partners-launch-10-minute-walk-campaign-partnership-fundand. Accessed 12 Oct 2020.

U.S. Bureau of the Census (2019) History: Urban and rural areas. https://www.census.gov/history/www/programs/geography/ urban_and_rural_areas.html. Accessed 28 Dec 2020.

U.S. Congress (2019) The green new deal. House Resolution 109, February 7, 2019. https://www.congress.gov/116/bills/hres109/ BILLS-116hres109ih.pdf. Accessed 11 Oct 2020.

Wallace-Wells D (2019) The uninhabitable earth: life after warming. Tim Duggan Books, New York

Weller R (2008) Landscape (Sub) urbanism in theory and practice. landscape Jrnl. January 1, 200827 (2): 247-267. doi: https://doi. org/10.3368/lj.27.2.247.

Williamson J, Dunham-Jones E (2020) Case studies in retrofitting suburbia: urban design strategies for urgent challenges. John Wiley \& Sons Inc, Hoboken

World Commission on Environment and Development (1987) Report of the world commission on environment and development: Our common future. United Nations, New York

World Population Review (2021). Portland, Oregon population 2021. https://worldpopulationreview.com/us-cities/portland-or-popul ation. Accessed 9 Apr 2021.

Xiang W-N (2019) Ecopracticality: the study of socio-ecological practice. Socio Ecol Pract Res 1(1):7-14. https://doi.org/10.1007/ s42532-019-00006-6

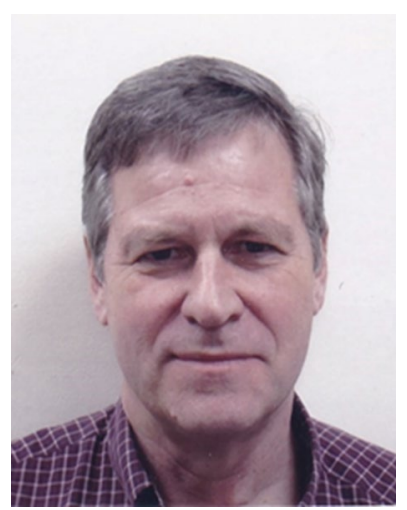

Tom Daniels Tom Daniels is Crossways Professor of City and Regional Planning at the University of Pennsylvania where he directs the concentration in Land Use Planning and Environmental Planning. He is the author of The Environmental Planning Handbook (American Planning Association, 2014). He is an editorial board member of SEPR. 